\title{
PRINS OF BOSWACHTER? \\ INTERPRETATIE VAN SUBJECTANAFOREN IN HET NEDERLANDS ALS TWEEDE TAAL ${ }^{1}$
}

\author{
MICHAL KOŘENÁŘ
}

\begin{abstract}
Prince or forester? An interpretation of subject anaphors in Dutch as a second language

This study aims to investigate offline processing of subject anaphora in Dutch. An important parameter in this study is the difference between pro drop and non-pro drop languages. An experiment has been run to investigate whether 27 Czechs that speak Dutch as a second language are able to interpret the referent belonging to a subject anaphora as well as 27 native Dutch speakers. These anaphors occurred in short Dutch stories with or without a topic shift, a cognitively demanding process where anaphors point to different referents in the story. One can expect this to lead to misinterpretation, especially in the case of groups of language users, whose cognitive capacities are already somehow compromised, such as the elderly or non-native speakers of a language. For the purposes of hierarchisation of subject anaphors, the Givenness Hierarchy has been used. To be able to determine the type of anaphora, the algorithm derived from the Centering Theory has been used. The study shows that Czechs fail to interpret the right referent of subject anaphora in the stories without the topic shift significantly more than the native Dutch control group. This can be explained by the interference between pro drop and non-pro drop languages. A pronoun signals a topic shift in Czech, while in Dutch, pronouns express topic continuity. Czechs often also incorrectly interpret the anaphora in the stories with a topic shift, although here the difference with the control group was not significant. This could be explained by the low number of parameters which have been considered during the experimental design.
\end{abstract}

Key words: subject anaphora; L2 acquisition; interference; pro drop; nonpro drop; Dutch; Czech

1 This research has been conducted within the project "Podpora védeckého výzkumu studentu doktorandů v oblasti obecné lingvistiky, srovnávací jazykovědy a fonetiky na FF UK v roce 2015", within the subproject “'Waar heb je het over?’ Uživání referenčních výrazů českými rodilými mluvčími $v$ L2-nizozemštine" at the Faculty of Arts, Charles University. This has been made possible by the financial support from Specific Academic Research in the year 2015. 


\section{Inleiding}

Een van de meest opvallende eigenschappen van verwijswoorden (anaforen) is dat ze niet goed geïsoleerd geïnterpreteerd kunnen worden. Hun betekenis is namelijk met andere elementen van een tekst verbonden. Zo ontstaat vanzelf de vraag: hoe is onze cognitie in staat de relaties tussen anaforen en andere tekstelementen te decoderen? Het blijkt dat er een complex mechanisme van cognitieve processen in werking wordt gesteld. Op grond van deze mechanismen wordt dan de juiste referent gekozen. (Koornneef 2008).

Een belangrijk fenomeen dat in moeilijke geheugenprocessen zoals leren een belangrijke rol speelt is cognitive load (Paas e.a. 2003, Sweller 2006). Omdat het decoderen van de juiste referent een complex cognitief proces is, is het redelijk te vermoeden dat een taalgebruiker hierin fouten maakt wanneer zijn of haar cognitieve belasting verhoogd wordt. Een dergelijke verhoging vindt bijvoorbeeld plaats wanneer het thema van een verhaal wordt veranderd. We spreken dan van topic shift (Garcia \& Joanette 2007). Hierbij dient aangetekend te worden dat dit niet tot misinterpretatie van anaforen leidt bij niet verder belaste taalgebruikers (Hendriks e.a. 2008). Een groep sprekers waarvan wel te verwachten valt dat ze anaforen in verhalen met topic shift fout kunnen interpreteren zijn niet-moedertaal sprekers. De informatie die ze ontvangen is namelijk niet in hun moedertaal, wat op zichzelf al een verhoogde cognitieve belasting inhoudt (De Bot e.a. 2005). Bij deze groep sprekers zijn natuurlijk nog andere factoren in het spel, zoals de leeftijd waarop ze hun tweede taal hebben verworven, hoe lang zij hun L2 al actief gebruiken, intelligentie, en hun houding tegenover de maatschappij van de doeltaal (eg. Appel en Vermeer 1996, Schumann 1978, Lenneberg 1967). Daarnaast is de mate waarin de L1 en L2 van de sprekers op elkaar lijken van invloed. Hierbij speelt de zogenaamde interferentie een grote rol. Het belangrijkste verschil tussen het Nederlands en het Tsjechisch dat door negatieve interferentie tot interpretatiefouten bij anaforen zou kunnen leiden, is de parameter pro-drop, non-pro-drop (Hendriks e.a. 2008).

Het verschijnsel waar dit artikel zich op richt zijn subjectanaforen, of, concreter nog, de perceptie van subjectanaforen door Tsjechen in het Nederlands, hun L2. Het doel is om er door een offline experiment achter te komen of er verschillen zijn in de vaardigheid verwijswoorden (in de rol van het subject) te interpreteren tussen moedertaalsprekers van het Nederlands en Tsjechische sprekers die Nederlands als L2 beheersen. Een dergelijke studie is voor dit talenpaar niet eerder gedaan. De resultaten van deze studie levert interessante informatie op over de rol van interferentie in het Nederlands bij Tsjechen wat betreft subjectanaforen, of algemener gesteld: interferentie in een L2 non-pro-drop taal vanuit een L1 pro-drop taal. Het biedt ook kostbare informatie over taalprocessing van subjectanaforen bij taalgebruikers met een verhoogde cognitieve belasting.

Een analoog onderzoek werd reeds uitgevoerd onder Italiaanse moedertaalsprekers die het Nederlands als L2 beheersen (Veenstra 2010). Veenstra veronderstelt dat de fouten die Italiaanse participanten in de interpretatie van de Nederlandse subjectanaforen maken, resulteren uit de interferentie van interpretatiestrategieën van subjectanaforen in hun moedertaal, een pro-drop-taal. Deze studie sluit dus aan bij het onderzoek over de invloed van de pro-drop/niet pro-drop-distinctie op de interpretatie van subjectanaforen in verhalen met of zonder topic shift. Als de resultaten overeenkomen met die 
van Veenstra, hebben we een ondersteunend bewijs dat de pro-drop-verschillen tussen de moedertaal en de tweede taal een belangrijke rol kunnen spelen in de tweede taalverwering.

In paragraaf 2 laat ik zien hoe subjectanaforen in het Tsjechisch werken. Als theoretisch kader wordt de Givenness Hierarchy van Gundel et al. (1993), de Centering Theory van Grosz et al. (1995) en Kehler's algoritme voor topic shift gebruikt (1997). Vervolgens laat ik zien hoe de interpretatiestrategie van anaforen in verhalen met topic shift in het Nederlands werkt. Vervolgens formuleer ik mijn hypotheses aan de hand van negatieve interferentie van de moedertaal bij Tsjechen die het Nederlands als tweede taal beheersen. In de daaropvolgende paragrafen zet ik mijn methodologie uiteen, vermeld ik de resultaten, en sluit ik deze studie af met een discussie.

\section{Subjectanaforen in het Tsjechisch vergeleken met het Nederlands}

\subsection{Hiërarchie van subjectanaforen in het Tsjechisch en het Nederlands}

In dit artikel wordt onder het begrip 'anafoor' altijd slechts een anafoor in de rol van het subject begrepen. Ik zal nu eerst met behulp van de Givenness Hierarchy van Gundel e.a. (1993) laten zien hoe deze verwijswoorden in het Tsjechisch werken. Volgens de theorie van Gundel e.a. signaleert de vorm van de anafoor in de tekst (zelfstandig naamwoord, voornaamwoord, nul voornaamwoord, etc.) aan de ontvanger van de informatie de belangrijkheid van de entiteit waarnaar verwezen wordt. Hun Givenness Hierarchy $(\mathrm{GH})$ onderscheidt verschillende graden van cognitieve belangrijkheid en op grond hiervan wordt ook de juiste vorm van de anafoor gebruikt. In hun werk wordt cognitieve belangrijkheid bepaald op basis van de mate van de bekendheid van de ontvanger met elementen in de tekst en de mate van de aandacht die de ontvanger besteedt aan deze elementen. De mate van aandacht wordt in hun werk givenness genoemd.

Tabel 1: Hiërarchie van anaforen in het Tsjechisch volgens de Givenness Hierarchy.

\begin{tabular}{|l|l|l|l|l|l|}
\hline $\begin{array}{l}\text { Referent in } \\
\text { het centrum } \\
\text { van } \\
\text { de aandacht }\end{array}$ & $\begin{array}{l}\text { Geactiverd - } \\
\text { niet in het } \\
\text { centrum, maar } \\
\text { nog steeds heel } \\
\text { toegankelijk }\end{array}$ & Familiaar & identificeerbaar & refererend & $\begin{array}{l}\text { Identificeerbaar } \\
\text { type }\end{array}$ \\
\hline Nolonderwerp & $\begin{array}{l}\text { Persoonlijk } \\
\text { voornaamwoord: } \\
\text { Já (ik), ty (jij), on } \\
\text { (hij), ona (zij), } \\
\text { ono (het), oni } \\
\text { (zij-meervoud, } \\
\text { manneliijk), etc. }\end{array}$ & $\begin{array}{l}\text { Aanwijzend } \\
\text { voornaamwoord: } \\
\text { Tyto (deze), tato } \\
\text { (die), toto (dit, } \\
\text { dat), etc. }\end{array}$ & $\begin{array}{l}\text { Aanwijzend } \\
\text { voornaamwoord } \\
\text { + zelfstandig } \\
\text { naamwoord: } \\
\text { Tento pes (deze } \\
\text { hond), tito muži } \\
\text { (deze mannen), } \\
\text { etc. }\end{array}$ & $\begin{array}{l}\text { Zelfstandig } \\
\text { naamwoord: } \\
\text { Pes (hond), } \\
\text { Hrad } \\
\text { (kasteel), } \\
\text { etc. }\end{array}$ & $\begin{array}{l}\text { Onbepaald } \\
\text { voornaamwoord } \\
\text { + zelfstandig } \\
\text { naamwoord: } \\
\text { Nějaký pes (een } \\
\text { honf), Někteří } \\
\text { lidé (sommige } \\
\text { mensen), etc. }\end{array}$ \\
\hline
\end{tabular}


Ze hebben de mogelijke vormen van de anaforen hiërarchisch gerangschikt waarbij op de hoogste positie de meest centrale referent staat. Zie Tabel 1, die geïnspireerd is op Gundel e.a. (1993), maar al wel aan het Tsjechisch aangepast.

In het geval van het Nederlands is de meest hiërarchische vorm een persoonlijk voornaamwoord, gevolgd door een aanwijzend voornaamwoord, gevolgd door bepaald lidwoord en zelfstandig naamwoord, gevolgd door onbepaald lidwoord en zelfstandig naamwoord, en ten slotte een onbepaald voornaamwoord en zelfstandig naamwoord.

Bij referenten die in het aandachtscentrum kunnen staan, kunnen ook hiërarchisch lagere anaforische vormen ingedeeld worden. Theoretisch zouden we dan voor het verwijzen in de tekst slechts zelfstandige naamwoorden kunnen gebruiken. Dit zou niet-economisch zijn. Om dit verschijnsel te vermijden gebruikt GH maximes van kwantiteit volgens Grice (1989):

1. Een uitspraak moet zo informatief zijn als nodig.

2. Een uitspraak zou niet meer informatief dan nodig moeten zijn.

Van deze maximes kunnen we dan een regel met betrekking tot GH extraheren: gebruik zo mogelijk de meest linkse anaforische vorm uit de GH tabel.

\subsection{Topic shift in het Tsjechisch en het Nederlands ten opzichte van subjectanaforen}

Deze bijdrage onderzoekt de correcte interpretatie van anaforen na optreden van topic shift. We doen daarvoor een beroep op de zogenaamde Centering Theory, een theoretisch kader dat zich naast de cognitieve status van de anaforen ook met tekstcoherentie bezighoudt (Grosz e.a. 1995). Volgens deze theorie wordt de continuiteit van een thema van een verhaal het makkelijkst door middel van een nulonderwerp gehandhaafd in een taal als het Tsjechisch. Binnen dit theoretisch kader worden tekstelementen ingedeeld op basis van hun belangrijkheid als verwijzer. Daarvoor wordt gekeken naar de syntactische functie in de zin. Het onderwerp staat het hoogst, dan volgt het lijdend of meewerkend voorwerp, et cetera. Alle referenten waarnaar in de tekst verwezen wordt, worden forward looking centers $(C f)$ genoemd. De meest prominente referent wordt preferred center $(C p)$ genoemd en correspondeert het frequentst met het onderwerp. De meest prominente referent waarnaar in een voorafgaande zin verwezen wordt, wordt in de eerstvolgende zin backward looking center $(\mathrm{Cb})$ genoemd. Sommige wetenschappers noemen dit topic (eg. Kruijff-Korbayova, Hajicova 1997). Voor de helderheid leg ik deze terminologie uit aan de hand van een concreet voorbeeld van de thematisering van een anafoor. ${ }^{2} \mathrm{Zie}(1)$.

(1)

A.Een prins ziet een goochelaar.

$\mathrm{Cf}=$ prins, goochelaar; $\mathrm{Cp}=$ een prins; $\mathrm{Cb}=<$ geen $>$

B. Hij probeert de goochelaar te doden.

2 Daar deze slechts voor de uitleg van terminologie dient, is het niet nodig een Tsjechisch voorbeeld te geven. 
$\mathrm{Cf}=$ prins, goochelaar; $\mathrm{Cp}=$ prins(uitgedrukt door hij); $\mathrm{Cb}=$ prins

C. Vervolgens faalt hij.

$\mathrm{Cf}=$ prins; $\mathrm{Cp}=$ prins(uitgedrukt door hij); $\mathrm{Cb}=$ prins

Met deze terminologie en methodologie werkt verder Kehler (1997) die op grond hiervan 3 basissituaties heeft beschreven die ten opzichte van de beweging en verandering van rollen van de centra in een tekst geobserveerd kunnen worden. Voor dit onderzoek is het slechts relevant het geval van topic shift te vermelden. Zie (2).

(2) “Center Shifting: : $\mathrm{Cb}\left(\mathrm{U}_{\mathrm{n}+1}\right) \neq \mathrm{Cb}\left(\mathrm{U}_{\mathrm{n}}\right)$."

In dit algoritme staat $U$ voor de uitspraak en $n$ voor de chronologische index van de concrete uitspraak. Met andere woorden: topic shift is een situatie, wanneer een anafoor de $\mathrm{Cb}$ van een huidige uitspraak is, maar niet van de daaropvolgende.

Dit algoritme helpt ook om te bepalen welke vormen een anafoor voor en na de topic shift heeft. Om hierachter te komen wordt het algoritme met het hiërarchische mechanisme van $\mathrm{GH}$ gecombineerd. De anafoor die in de laatste zin een $\mathrm{Cb}$ is, het thema, heeft de hiërarchisch hoogste staat. In het geval van het Tsjechisch, een pro-drop taal, zal het het vaakst een nulonderwerp zijn. In de volgende uitspraak moet in het geval van de topic shift een nieuwe Cp (her)ingeleid worden. Dit kunnen we gemakkelijker bereiken als we de gewenste anafoor de rol van het onderwerp laten vervullen. We proberen dan telkens met de hiërarchisch hoogste vorm van de anafoor naar het antecedent te verwijzen, namelijk met het nulonderwerp. Het gebeurt echter heel vaak dat de anafoor in de rol van het nieuwe thema dubbelzinnig geïnterpreteerd kan worden - het antecedent wordt in het Tsjechisch in het geval van een nulonderwerp namelijk slechts door middel van een morfologische vorm van het werkwoord aangeduid. Als het nieuwe thema en ook het thema van de vorige uitspraak beide dezelfde persoonscategorie hebben, is het lastig deze twee van elkaar te onderscheiden. Zie (3):

(3) A. Princ jde lesem

Prins $_{\text {nominatief }}$ loopt $3 . p$, enkelvoud bos $_{\text {instrumentaal }}$

Een prins loopt door een bos.

B. Potká myslivce.

Ontmoet $3 . p$, enkelvoud boswachter $_{\text {accusatief, mannelijk }}$

Hij ontmoet een boswachter.

C. a. Zeptá se ho na cestu.

Vraagt $_{3 \text {.p.enkelvoud }}$ zich $_{\text {accusastief }}$ hem genitief $_{\text {naar weg accusatief }}$.

Hij(=prins) vraagt hem naar de weg.

b. On se ho zeptá na cestu.

$\mathrm{Hij}_{\text {nominatief }}$ zich $_{\text {accusastief }}$ hem genitief vraagt $_{3 . p \text {, enkelvoud }}$ naar weg accusatief

Hij(=boswachter) vraagt hem naar de weg.

In zin $(3 \mathrm{Ca})$ is het in orde het nulonderwerp als anafoor te gebruiken in het geval we de continuïteit van het thema willen uitdrukken, namelijk, dat de prins de boswachter naar de weg vraagt. Als we het thema hier willen veranderen, stuiten we op een probleem, 
namelijk dat beide thema's mannelijk enkelvoud zijn. Daarom moeten we de topic shift expliciet maken door een lagere hiërarchische graad voor het nieuwe thema te gebruiken. In het Tsjechisch is dat een persoonlijk voornaamwoord. In het Nederlands markeert men de topic shift in deze situatie echter door een bepaald lidwoord en zelfstandig naamwoord te gebruiken.

Op deze manier kan de spreker de topic shift aan de hand van de verandering van de hiërarchie van Cf herkennen. De Tsjechische spreker ziet het persoonlijke voornaamwoord als een markeerfactor voor de topicshift, omdat dit verschijnsel in zijn moedertaal op deze manier wordt gemarkeerd. Een Nederlandstalige zou in dit soort dubbelzinnige gevallen het nieuwe thema door middel van een bepaald lidwoord en zelfstandig naamwoord herkennen.

\section{Onderzoeksvragen}

Het gebruik van een taal die niet de moedertaal is, is cognitief veeleisend. In combinatie met andere aspecten die de cognitieve belasting verhogen, eg. topic shift, wordt het nog lastiger correct de vreemde taal te gebruiken en te begrijpen. (De Bot e.a. 2005).

Mijn eerste onderzoeksvraag luidt dan ook als volgt:

1. Kan de cognitieve belasting bij een niet-moedertaal spreker tot een foute interpretatie van het juiste antecedent bij subjectanaforen in verhalen met een topic shift leiden?

Interferentie van de moedertaal in de tweede taal is een psycholinguïstisch verschijnsel dat veroorzaakt dat regels van de moedertaal over worden genomen door het andere taalsysteem, de tweede taal. Ik ga ervan uit dat de tweedetaalleerders, nog steeds in hun Window of Opportunity-fase, via hun eerste taal indirecte toegang tot de universele grammatica hebben (Gass \& Schachter 1989, Bley-Vroman 1989). Deze spiegelt zich dan echter ook in de negatieve interferentie, voor al als de twee talen veel van elkaar verschillen.

Er is al onderzoek gedaan naar asymmetrie in de productie tussen non-pro-drop en pro-drop talen op grond van de subjectanafoor Galasso 2002). Hieruit blijkt dat Spaanse sprekers van het Engels, dus L1-sprekers van een pro-drop taal, in hun spontane Engels niet zelden een nulonderwerp gebruiken. In een andere studie laten Sorace en Filiaci (2006) zien dat Engelse sprekers van L2-Italiaans problemen hebben met de interpretatie van een voornaamwoord dat naar een ander antecedent verwijst dan het onderwerp van de voorafgaande zin. Deze zijn volgens Sorace en Filiaci te verklaren door de negatieve interferentie vanuit hun moedertaal. Uit voornoemde onderzoeken volgt dat er zowel invloed is van de pro-drop moedertaal op de non-pro-drop tweede taal als van de nonpro-drop moedertaal op de pro-drop tweede taal.

In mijn onderzoek worden slechts gevorderde sprekers van het Nederlands (niveau $\mathrm{C} 1$ en hoger) getest. We verwachten dus dat de reden voor fouten in de interpretatie van anaforen niet aan onvoldoende taalkennis ligt, maar dat er gedacht moet worden aan interferentie van de interpretatiestrategie vanuit de moedertaal. Daarom luidt mijn tweede onderzoeksvraag als volgt: 
2. Zullen Tsjechische sprekers van het Nederlands, hun tweede taal, fouten in de interpretatie van subjectanaforen maken in Nederlandse korte verhalen met een topic shift?

\section{Hypotheses}

Garcia en Joanett (1997) laten zien dat topic shift een duidelijke verhoging van de cognitieve belasting veroorzaakt. Andere onderzoekers veronderstellen dat het gebruik van een andere taal dan de moedertaal op zich al een markante verhoging van de cognitieve belasting betekent. (De Bot e.a. 2005, Bialystok 1997, Molis 2001). Ook is aangetoond dat de mate van cognitieve belasting de succesvolle uitvoering van complexere cognitieve operaties negatief kan beïnvloeden (Paas e.a. 2003, Sweller 2006) en zoals Garcia en Joanett (1997) lieten zien, behoort de interpretatie van antecedenten van anaforen na een topic shift tot dit soort processen. Ik veronderstel bijgevolg dat:

3. Tsjechen die het Nederlands als tweede taal gebruiken, geregeld zullen falen in de interpretatie van het antecedent in een Nederlandstalig verhaal met topic shift en Nederlandse moedertaalsprekers niet of minder.

Zoals het algoritme van Kehler (1997) afgeleid van the Centering Theory in combinatie met de hiërachie van anafoorvormen uit de Givenness Hierarchy voorspelt, gebruiken Tsjechen voor het markeren van topic shift in dubbelzinnige gevallen het frequentst een persoonlijk voornaamwoord (Dušková 2012). In het Nederlands wordt het persoonlijk voornaamwoord echter gebruikt om de continuïteit van een verhandeling uit te drukken. Daarom veronderstel ik dat:

4. Tsjechen die het Nederlands als tweede taal gebruiken, geregeld zullen falen in de interpretatie van het antecedent in een Nederlandstalig verhaal waar geen topic shift optreedt en Nederlandse moedertaalsprekers niet of minder.

Dit beredeneer ik door de negatieve interferentie tijdens de taaltransfer vanuit het Tsjechisch, pro-drop taal, naar het Nederlands, non-pro-drop taal.

\section{Methodologie}

Voor de toetsing van mijn hypotheses heb ik een offline processing experiment uitgevoerd.

\subsection{Participanten}

Aan mijn onderzoek hebben als proefpersonen 27 Tsjechen (10 mannen en 17 vrouwen) deelgenomen, die in Nederland leven en Nederlands in hun alledaagse leven gebruiken, en 27 Nederlanders (14 mannen en 13 vrouwen) die als controlegroep fungeerden. Sommige Tsjechische proefpersonen heb ik via de Tsjechische ambassade in Den Haag 
gecontacteerd, anderen via contacten met landgenoten in Nederland. Alle deelnemers hebben opgegeven dat ze niet aan taalstoornissen leiden.

Er waren een aantal extra voorwaardes voor de Tsjechische participanten:

- ze moesten in Tsjechië geboren zijn en daar de eerste tien jaar van hun leven doorgebracht hebben teneinde te garanderen dat hun kritische periode afgerond is en Tsjechisch de prominente positie van de moedertaal inneemt (Appel en Vermeer 1996),

- hun taalvaardigheid van het Nederlands moest op het niveau C1 of hoger zijn zodat er in het geval van falen in de interpretatie van de verwijswoorden geen sprake kan zijn van onvoldoende taalkennis.

Aan deze voorwaarde werd voldaan door het bezit van het Certificaat Nederlands als Vreemde Taal, het niveau PAT, of Educatief Professioneel, of het Staatsexamen NT2, Programma II. Als ze een universitair diploma van een Nederlandstalige studie hadden behaald of met succes het inburgeringsexamen afgelegd ging ik er tevens van uit dat aan voornoemde voorwaarde was voldaan.

Beide groepen moesten daarnaast aan deze voorwaarden voldoen:

- leeftijd tussen 18 en 50 jaar. Deze grens werd bepaald op basis van het werk van Glisky (2007), die de ontwikkelingsfysiologie van de hersenen onderzocht heeft en de invloed hiervan op cognitieve functies. De jongste proefpersoon was 23, de oudste 48.

- een diploma uit het tertiair onderwijs of ten minste student zijn in het tertiair onderwijs. Ik wilde een consistente groep qua onderwijsniveau hebben. Onderzoeken laten namelijk zien, dat onderwijsniveau met een aantal psychologische en sociologische factoren correleert (Tinto, 1975; White, 1982).

Eén proefpersoon vormde een uitzondering omdat ze weliswaar nooit aan een universiteit had gestudeerd, maar wel op universitair niveau les had gegeven.

\subsection{Enquête}

Om mogelijk afwijkende resultaten van proefpersonen op basis van buitentalige factoren te kunnen verklaren, heb ik besloten de Tsjechische proefpersonen een enquête in te laten invullen. Li, Sepanski en Zao (2006) hebben een passend formulier bedacht dat ik in mijn onderzoek heb gebruikt. Resultaten van de enquête worden in het hoofdstuk 5. Resultaten beschreven. De relevante factoren die in het formulier werden afgetast, zijn geslacht, leeftijd (Glisky 2007), motivatie om de taal te leren (Appel en Vermeer 1996), hoe geaccepteerd de spreker zich in de maatschappij voelt (Appel en Muysken 1988)3 intelligentie (Lenneberg 1967), hoe goed de spreker zijn eerste taal beheerst (Appel en Vermeer 1996), welke andere talen hij beheerst, hoe lang hij met zijn tweede taal bezig is, of hij zijn tweede taal dagelijks gebruikt (Bialystok 1997).

\subsection{Materiaal}

Voor mijn experiment heb ik 8 Nederlandstalige verhalen gemaakt, elk samengesteld uit 6 zinnen waar twee personen van hetzelfde geslacht in voorkwamen. Deze verhalen

3 Schumann (1978) spreekt over de attitude van de spreker afhankelijk van zijn relatie en gevoelens richting de maatschappij van zijn tweede taal in the Accultaration Theory 
zijn in de Appendix van dit artikel te vinden. Alle verhalen werden door een Nederlandstalige moedertaalspreekster voorgelezen en opgenomen. Vier verhalen waren zonder topic shift. Zie (4).

(4)

Een boswachter vaart over de zee.

Hij vindt varen heel rustgevend.

Hij vaart samen met een goochelaar.

De boswachter vraagt de goochelaar om een sigaretje.

Toevallig vindt de boswachter nog een sigaretje in zijn tas.

Hij gaat daarna een biertje drinken.

En vier verhalen waren met topic shift. Zie (5).

(5)

Een boer is paddenstoelen aan het plukken.

Hij kan geen paddenstoelen vinden.

Hij ziet een prins met heel veel paddenstoelen in zijn handen.

De prins geeft de boer wat paddenstoelen.

Daarna neemt de prins afscheid van de boer.

Hij gaat dan lekker in de zon liggen.

$\mathrm{Na}$ het beluisteren van het verhaal (altijd slechts één keer) werd de proefpersonen gevraagd te zeggen waar het voornaamwoord in de laatste zin naar verwijst. In verhalen zonder topic shift is het juiste antwoord referent 1 , bij verhalen met de topic shift is dat referent 2 .

\subsection{Uitvoering van het experiment}

Alle experimenten werden in een stille kamer op de universiteit of bij proefpersonen thuis uitgevoerd. Aan alle deelnemers werd uitgelegd waar de data uit het experiment voor zouden worden gebruikt. Daarna werd hun gevraagd of ze nog steeds met het experiment mee wilden doen. De Tsjechische deelnemers moesten eerst een kopie van een document laten zien als bewijs van hun voldoende taalvaardigheid in het Nederlands. Tsjechen moesten vervolgens nog de taalenquête invullen. Daarna werd het eigenlijke experiment uitgevoerd. De verhalen werden steeds slechts eenmalig door middel van een HP EliteBook 8440p afgespeeld. Na het afspelen werd meteen de vraag naar het antecedent van het laatste voornaamwoord gesteld. Omdat het geen online experiment was, hadden de deelnemers onbeperkte tijd om over hun antwoord na te denken. De verhalen werden in willekeurige volgorde afgespeeld met behulp van de functie shuffle van het programma Windows Media Player. 


\section{Resultaten}

De proefpersonen werd gevraagd naar het antecedent van de anafoor in de laatste zin. Zie (4) en (5). Er is op de resultaten een variantieanalyse (ANOVA) uitgevoerd met factoren antwoord (referent 1 of 2), topic shift (ja of nee), en groep (Nederlanders, Tsjechen). In de interactie van de drie factoren is er een significant effect $(\mathrm{p}<0,05)$ gevonden. De follow up analyse heeft laten zien dat de kern van dit effect waarschijnlijk het verschil tussen Tsjechen en Nederlanders is, in verhalen met en ook zonder topic shift. Zie tabel 2.

Tabel 2: Antwoorden.

\begin{tabular}{|l|c|c|c|c|}
\hline & Nederlanders & Nederlanders & Tsjechen & Tsjechen \\
\hline & Referent 1 & Referent 2 & Referent 1 & Referent 2 \\
\hline Met topic shift & $12 \%$ & $88 \%$ & $24 \%$ & $73 \%$ \\
\hline Zonder topic shift & $91 \%$ & $9 \%$ & $70 \%$ & $30 \%$ \\
\hline
\end{tabular}

Een subsequente t-test liet zien dat de verschillen in het succes van de interpretatie bij Tsjechen en Nederlanders in het geval van antwoorden zonder topic shift significant waren. De standaardfout was bij geen van de gevallen groter dan $5 \%$.

Om deze resultaten samen te vatten: geen van de groepen heeft foutloos gescoord. Desalniettemin hebben Tsjechen significant vaker in verhalen zonder topic shift de laatste anafoor foutief ingedeeld $(t=2,52 ; \mathrm{p}<0,05)$. Er leek onder Tsjechen ook een sterkere neiging te bestaan om bij verhalen met topic shift de referent foutief in te delen dan bij de controlegroep. De $t$-test heeft laten zien dat dit effect niet significant is $(t=1,34 ; p=0,12)$.

Zoals hierboven vermeld is de Tsjechische proefpersonen gevraagd een enquête in te vullen om erachter te komen of factoren buiten de taal een belangrijke rol spelen. Variantieanalyse heeft geen statistisch significante correlaties tussen de gegevens ingevuld in de enquête (informatie over geslacht, leeftijd, motivatie, kennis van andere vreemde talen) en de resultaten van het experiment laten zien.

\section{Discussie}

In het in dit artikel beschreven experiment moesten de proefpersonen vaststellen welke van de twee in een verhaal voorkomende personen de referent van de anafoor in de laatste zin is. Bij verhalen met topic shift verwijzen anaforen in de eerste drie zinnen van het verhaal naar de eerste referent, en in de vierde zin en ook in de laatste zin naar de tweede referent. Bij verhalen zonder topic shift blijft de eerste referent in het centrum van de aandacht en in alle zinnen van het verhaal wordt naar hem verwezen door middel van het onderwerp.

Bij verhalen zonder topic shift bleken Tsjechische gebruikers van het Nederlands significant vaker de foute referent van de laatste anafoor in het verhaal te interpreteren. Dit 
verschijnsel kunnen we door middel van de negatieve interferentie tussen de pro-drop moedertaal en de non-pro-drop tweede taal verklaren.

Als we naar het algoritme van topic shift kijken (Kehler 1997) en dat in verband brengen met de hiërarchische stratificatie van anaforen zoals deze in tabel 1 wordt beschreven (Gundel e.a. 1993), dan komen we tot volgende conclusie: Tsjechisch als pro-drop taal heeft de hiërarchie van anaforen verschoven naar links vergeleken met het Nederlands, een non-pro-drop taal. De hiërarchisch hoogste positie wordt in het Tsjechisch namelijk door het nulonderwerp ingenomen. Daarentegen is de hoogste positie in het Nederlands 'slechts' het persoonlijk voornaamwoord.

In gevallen van potentiele dubbelzinnigheid qua interpretatie van anaforen na een topic shift is het nodig de topic shift door een verlaging van de hiërarchie van de anafoor te markeren. Vanwege de verschoven hiërarchie van anaforen in beide talen zijn de indicatoren van de topic shift voor de sprekers van de taal verschillend: in het Tsjechisch het frequentst een persoonlijk voornaamwoord, in het Nederlands een zelfstandig naamwoord met bepaald lidwoord.

Ter illustratie van de Tsjechische interpretatiestrategie, die beïnvloed wordt door de interferentie van het Tsjechisch in het L2-Nederlands, zie (6).

Een boswachter vaart over de zee.

Myslivec pluje přes moře.

(Hij) vindt varen heel rustgeven.

Plavbu shledává velmi uklidňující.

(Hij) vaart samen met een goochelaar.

Pluje společně s čarodějem.

De boswachter vraagt de goochelaar om een sigaretje.

Myslivec požádá čaroděje o cigaretu.

Toevalig vindt de boswachter nog een sigaretje in zijn tas.

Náhodou najde myslivec ještě jednu cigaretu ve své tašce.

A.(Hij) (=boswachter) gaat daarna een biertje drinken.

Pak si jde dát jedno pivo.

B.Hij (=goochelaar) gaat daarna een biertje drinken.

On si pak jde dát jedno pivo.

Wanneer een Tsjech wil uitdrukken dat de goochelaar een biertje gaat drinken, gebruikt hij zin (6B), omdat het persoonlijk voornaamwoord de topic shift signaleert. In het Nederlandse verhaal ziet hij het equivalent van (6B) in het geval van een continuerend verhaal. Hier kunnen we dus duidelijk zien dat de falende Tsjechen de interpretatiestrategie vanuit hun moedertaal in de tweede taal probeer te gebruiken. 
Veenstra (2010) heeft in haar onderzoek naar de interpretatie van subjectanaforen in L2 het Nederlands van Italiaanse moedertaalsprekers bekeken. Italiaans is net zoals Tsjechisch een pro-drop taal. Ik gebruik in mijn onderzoek een methodologie die vergelijkbaar is met de hare. De hier gepresenteerde resultaten komen overeen met die van Veenstra (2010). Ook in haar onderzoek maakten de Italiaanse sprekers significant meer fouten in de interpretatie van verhalen zonder topic shift dan de Nederlandse controlegroep. In de verhalen met topic shift maakten zowel Nederlanders als Italianen fouten in de interpretatie van de referent van de laatste zin.

In mijn onderzoek heeft zelfs de controlegroep niet foutloos gepresteerd in de verhalen met topic shift. Daarom waren de verschillen tussen Nederlanders en Tsjechen in de interpretatie van dit type zinnen statistisch niet significant. Ik kan een mogelijke verklaring voor deze resultaten bieden. Song en Fisher (2007) hebben parameters beschreven die volgens hen een rol spelen in de keuze van het antecedent van een anafoor. De parameters zijn: onderwerp in de voorafgaande zin, hoe vaak wordt een referent vermeld, welke referent wordt als eerste vermeld en hoe vaak wordt naar de referent door middel van voornaamwoorden verwezen. Deze parameters bepalen de mate van prominentie van referenten. Met andere worden, als een referent als eerste en bovendien frequent vermeld wordt in de rol van subject en als naar deze referent, vaak door middel van voornaamwoorden, verwezen wordt, dan zal deze waarschijnlijker als de referent van een ambigue anafoor geïnterpreteerd worden. Zelfs de controlegroep had problemen met de interpretatie van de referenten van ambigue anaforen bij verhalen met de topic shift. Voor de parameters die werkzaam zijn bij verhalen met de topic shift zie tabel 3.

Zoals tabel 3 aangeeft, wordt referent 1 vijf keer in het verhaal vermeld. Dit maakt van deze referent de prominentere referent voor de interpretatie. Referent 2 wordt in het verhaal slechts drie keer vermeld. Bovendien wordt referent 2 als de eerste referent in het verhaal genoemd en ook als het laatste subject van het verhaal. Aan de andere kant wordt naar referent 1 vaker door middel van een voornaamwoord verwezen. Dat betekent dat de prominentie van beide referenten door 2 van de 4 parameters wordt ondersteund. Referent 2 is dus niet automatisch een duidelijke keuze voor de interpretatie van de ambigue anafoor in de laatste zin. Ook al wordt de parameter van de laatste vermelding als de sterkste parameter beschouwd (Song en Fischer 2007, Sanders en Gernsbacher 2004), is het waarschijnlijk toch belangrijk dat de prominentie van een referent door meer factoren wordt ondersteund. Dit kan dus de reden zijn waarom zelfs de controlegroep niet foutloos de laatste referent heeft geïnterpreteerd. Als oplossing voor deze situatie zou in het experimenteel design nog een zin opgenomen kunnen worden waarin referent 2 nog een keer als subject van de zin vermeld wordt.

\section{Conclusie}

Het doel van dit artikel was de interpretatievaardigheid van subjectanaforen in het Nederlands bij moedertaalsprekers en bij Tsjechen die het Nederlands als tweede taal op het niveau C1-C2 beheersen, te vergelijken. Ik veronderstel dat negatieve taalinterferentie vanuit de moedertaal bij Tsjechen tot misinterpretatie van anaforen kan leiden (zowel bij 
Tabel 3: Parameters die de prominentie van referenten bepalen.

\begin{tabular}{|c|c|c|c|c|c|c|}
\hline & \multicolumn{3}{|c|}{ Referent 1 (=sedlák, de boer) } & \multicolumn{3}{|c|}{ Referent 2 (=princ, de prins) } \\
\hline & $\begin{array}{c}\text { Voornaam- } \\
\text { woord }\end{array}$ & subject & vermeld & $\begin{array}{c}\text { Voornaam- } \\
\text { woord }\end{array}$ & subject & vermeld \\
\hline $\begin{array}{l}1 \text { Een boer is } \\
\text { paddenstoelen } \\
\text { aan het plukken. } \\
\text { Sedlák sbirá } \\
\text { houby. }\end{array}$ & & $\mathrm{x}$ & $\mathrm{x}$ & & & \\
\hline $\begin{array}{l}2 \text { Hij kan geen } \\
\text { paddenstoelen } \\
\text { vinden. } \\
\text { On nemůže žádné } \\
\text { houby najit. }\end{array}$ & $\mathrm{x}$ & $\mathrm{x}$ & $\mathrm{x}$ & & & \\
\hline $\begin{array}{l}3 \text { Hij ziet } \\
\text { een prins } \\
\text { met heel veel } \\
\text { paddenstoelen in } \\
\text { zijn handen. } \\
\text { On uvidí prince } \\
\text { s hodně houbami } \\
\text { v rukách. }\end{array}$ & $\mathrm{x}$ & $\mathrm{x}$ & $\mathrm{x}$ & & & $\mathrm{x}$ \\
\hline $\begin{array}{l}4 \text { De prins geeft } \\
\text { de boer wat } \\
\text { paddenstoelen. } \\
\text { Princ dá } \\
\text { sedlákovi nějaké } \\
\text { houby. }\end{array}$ & & & $\mathrm{x}$ & & $\mathrm{x}$ & $\mathrm{x}$ \\
\hline $\begin{array}{l}5 \text { Daarna neemt } \\
\text { de prins afscheid } \\
\text { van de boer. } \\
\text { Pak se princ } \\
\text { se sedlákem } \\
\text { rozloučí. }\end{array}$ & & & $\mathrm{x}$ & & $\mathrm{x}$ & $\mathrm{x}$ \\
\hline $\begin{array}{l}6 \text { Hij gaat dan } \\
\text { lekker in de zon } \\
\text { liggen. } \\
\text { On si pak jde } \\
\text { lehnout na } \\
\text { sluníčko. }\end{array}$ & & & & & $\mathrm{x}$ & $\mathrm{x}$ \\
\hline totaal & 2 & 3 & 5 & 0 & 2 & 3 \\
\hline
\end{tabular}

verhalen met als bij verhalen zonder topic shift). Mijn hypotheses zijn gebaseerd op een aantal onderzoeken die laten zien dat de cognitieve belasting bij niet-moedertaalsprekers op zich al hoog is, zeker als in de zin topic shift optreedt. Ik verwacht een negatief effect wat betreft de interpretatie van subjectanaforen in verhalen zonder topic shift omdat Tsjechen en Nederlanders andere interpretatiestrategieën gebruiken. Deze verschillen worden beschreven aan de hand van een verschil in hiërarchie van vormen van anaforen, die dan als indicator van topic shift of continuïteit van een thema in een verhaal kunnen dienen. Mijn verwachtingen worden ook ondersteund door het onderzoek van Veenstra (2010). 
Ik heb geprobeerd mijn hypothese experimenteel te bevestigen. De resultaten laten zien dat Tsjechische sprekers van het L2-Nederlands significant vaker de foute referent in de laatste zin van het verhaal zonder topic shift hebben geïnterpreteerd dan de controlegroep van Nederlandstaligen. Hiermee is hypothese 2 bevestigd.

Hypothese 1, namelijk dat Tsjechen vanwege te hoge cognitieve belasting ook in het geval van verhalen met topic shift zullen falen in de interpretatie van de juiste referent, wordt niet bevestigd vanwege de tamelijk hoge $p$ waarde. We kunnen dit resultaat zo proberen te interpreteren dat de cognitieve belasting bij geavanceerde L2-gebruikers van het Nederlands een kleinere rol speelt dan de invloed vanuit hun moedertaal. Hun foutenfrequentie was niet significant hoger dan die van de moedertaalsprekers Nederlands. Om zoiets echter met zekerheid te kunnen zeggen, is het nodig zijn om het experiment met een groter aantal proefpersonen opnieuw uit te voeren en na te gaan hoe de $p$ waarde zich dan ontwikkelt. Het is ook nodig het experimentele design aan te passen aan de hand van onderzoek van Song en Fisher (2007), omdat zelfs de controlegroep problemen had met de interpretatie van de juiste referent in de verhalen met topic shift.

Veenstra (2010) heeft een analoog onderzoek met vergelijkbare resultaten uitgevoerd. Leden van de doelgroep in haar onderzoek waren sprekers van een andere pro-drop taal, het Italiaans. De tweede taal die ze leerden was opnieuw het Nederlands. Ook in haar werk hebben de niet-moedertaalsprekers significant meer fouten in zinnen zonder topic shift gemaakt, dan de controlegroep. Veenstra vermoedt dat de verhoogde kans op fouten in de doelgroep door de interpretatiestrategieën vanuit de pro-drop moedertaal wordt veroorzaakt. Zowel Veenstra's als mijn onderzoeksresultaten laten zien dat vervolgonderzoek onontbeerlijk is waarbij gekeken zou moeten worden naar andere structurele verschillen tussen het Nederlands en andere talen. Bovendien zou dit onderzoek op een veel grotere groep participanten gebaseerd moeten worden om tot statistisch significante resultaten te komen.

\section{BIBLIOGRAFIE}

APPEL, RENÉ \& MUYSKEN, PIETER (1988). Language Contact and Bilingualism. Londen: Arnold.

APPEL, RENÉ \& VERMEER, ANNE (1996). Tweede-taalverwerving en tweede-taalonderwijs. Bussum: Coutinho.

BIALYSTOK, ELLEN (1997). “The structure of age: In search of barriers to second-language acquisition”, in: Second Language Research 13, 116-137.

BLEY-VROMAN, ROBERT; FELIX, SASCHA \& LOUP, GEORGETTE (1989). “The accessibility of Universal Grammar in adult language learning”, in: Second Language Research 4, 1-32.

DE BOT, KEES; LOWIE, WANDER \& VERSPOOR, MARJOLYN (2005). Second Language Acquisition: an Advanced Resource Book. Routledge: London.

DUŠKOVÁ, LUDMILA (2012). "Modifikovaná substantivní fráze jako komponent textové výstavby $\mathrm{v}$ angličtině a češtině”, in: Journal for Modern Philology 94, 1, 1-18.

GALASSO, JOSEPH (2002). Interference in Second Language Acquisition: A Review of the Fundamental Difference Hypothesis Transferring the 'Pro-drop' Parameter from Spanish to English. Retrieved January 31, 2016, from California State University Web site: http://www.csun.edu/ galasso/pro.htm.

GARCIA, LINDA \& JOANETTE, YVES (2007). "Analysis of Conversational Topic Shifts: A Multiple Case Study", in: Brain and Language, 92-114.

GASS, SUSAN \& SCHACHTER, JACQUELYN (1989). "Introduction", in: Linguistic Perspectives on Second Language Acquisition, 1-10. 
GLISKY, ELIZABETH (2007). "Changes in Cognitive Function in Human Aging”, in: David Riddle (red.): Brain aging: Models, methods, and mechanisms. Boca Raton: CRC Press.

GRICE, PAUL (1989). Studies in the way of words. Harvard University Press: Cambridge.

GROSZ, BARBARA. J.; JOSHI, ARAVIND. K. \& WEINSTEIN, SCOTT (1995). "Centering: A Framework for Modelling the Local Coherence of Discourse", in: Computational Linguistics 21, 203-225.

GUNDEL, JEANETTE e.a. (1993). "Cognitive Status and the Form of Referring Expressions in Discourse”, in: Language 69, 274-307.

HENDRIKS, PETRA e.a. (2008). "Age differences in adults' use of referring expressions", in: Journal of Logic, Language and Information 17, 443-466.

KEHLER, ANDREW (1997). "Current Theories of Centering for Pronoun Interpretation: A Critical Evaluation", in: Computational Linguistics 23, 3, 467-475.

KOORNNEEF, ARNOUT WILLEM (2008). Eye-catching anaphora. Utrecht: LOT International Dissertation Series.

KRUIJFF-KORBAYOVA, IVANA \& HAJICOVA, EVA (1997). "Topics and Centers: A Comparison of the Salience-based Approach and the Centering Theory”, in: Prague Bulletin of Mathematical Linguistics $67,25-50$.

LENNEBERG, ERIC H. (1967). Biological Foundations of Language. John Wiley \& Sons: Hoboken (New Jersey).

LI, PING e.a. (2006). "Language history questionnaire: A web-based interface for bilingual research", in: Behavior Research Methods 38, 202-210.

MOLIS, MICHELLE (2001). "On the Evidence for Maturational Constraints in Second-Language Acquisition", in: Journal of Memory and Language 44, 235-249.

PAAS, FRED e.a. (2003). “Cognitive Load Theory and Instructional Design: Recent Developments", in: Educational Psychologist 38, 1, 1-4.

SANDERS, TED \& GERNSBACHER MORTON ANN (2004). "Accessibility in text and discourse processing", in: Discourse Processes 37, 2, 79-89.

SCHUMANN, JOHN (1978). "The Acculturation Model for Second Language Acquisition”, in Rosario Gingras (red.): Second Language Acquisition and Foreign Language Teaching, Arlington (USA): Center for Applied Linguistics, 27-51.

SORACE, ANTONELLA \& FILIACI, FRANCESCA (2006). "Anaphora resolution in near-native speakers of Italian", in: Second Language Research 22, 3, 339-368.

SWELLER, JOHN (2006). "Discussion of 'emerging topics in cognitive load research: Using learner and information characteristics in the design of powerful learning environments", in: Applied Cognitive Psychology 20, 3, 353-357.

TINTO, VINCENT (1975). "Dropout from higher education: A theoretical synthesis of recent research", in: Review of educational research 45, 1, 89-125.

VEENSTRA, ALMA (2010). Subject Anaphora in L2 Dutch of Native Italian Speakers. Unpublished MA thesis. University of Groningen.

WHITE, KARL (1982). "The relation between socioeconomic status and academic achievement", in: Psychological bulletin 91, 3, 461.

\section{PRINC NEBO HAJNÝ? INTERPRETACE PODMĚTOVÝCH ANAFOR V NIZOZEMŠTINĚ JAKO DRUHÉM JAZYCE}

Cílem této studie je prozkoumat offline zpracování anafor v podmětu v nizozemštině. Dủležitým parametrem této studie je rozdíl mezi pro drop jazykem (jazyk, který může vynechat některé typy zájmen) a non-pro drop jazykem. Byl proveden pokus prověřit, zda 27 Čechů, kteří používají nizozemštinu jako svůj druhý jazyk, je schopno interpretovat referent, který patří k anafoře v podmětu, stejně dobře jako 27 nizozemských rodilých mluvčích. Tyto anafory se vyskytovaly v krátkých nizozemských příbězích s tematickým posunem nebo bez něj, což je kognitivně náročný proces, kdy anafory ukazují na různé referenty v př́iběhu. Lze očekávat, že to vede $\mathrm{k}$ nesprávné interpretaci, zejména $\mathrm{v}$ př́ípadě skupin uživatelů, jejichž kognitivní 
schopnosti jsou již nějakým způsobem ohroženy, jako jsou např́ílad starší lidé nebo lidé, pro které je nizozemština cizím jazykem. Pro účely hierarchizace anafor v podmětu byla použita Giveness hierarchy. Abychom byli schopni určit typ anafory, byl použit algoritmus odvozený z tzv. Centering Theory. Studie ukazuje, že Češi nedokáží interpretovat správného referenta podmětové anafory v příbězích bez tematického posunu výražně častěji než kontrolní skupina rodilých mluvčích nizozemštiny. To lze vysvětlit interferencí mezi pro drop a non-pro drop jazyky. $\mathrm{V}$ češtině zájmeno signalizuje změnu tématu, zatímco v nizozemštině zájmena naopak vyjadřují tematickou kontinuitu. Češi také často nesprávně interpretují anaforu v př́bězích s tematickým posunem, ačkoli v tomto př́padě rozdíl s kontrolní skupinou nebyl významný. To lze vysvětlit nízkým počtem parametrů, které jsme vzali v úvahu během experimentálního návrhu.

\section{APPENDIX}

Verhalen met topic shift

1 .

Een soldaat fiets door een bos.

Hij vindt het erg door het bos alleen te fietsen.

Hij komt plotseling een kabouter tegen.

De kabouter ziet dat de soldaat bang is.

De kabouter wil de soldaat door het bos begeleiden.

Hij is er best enthousiast over.

\section{2.}

Een boer is paddenstoelen aan het plukken.

Hij kan geen paddenstoelen vinden.

Hij ziet een prins met heel veel paddenstoelen in zijn handen.

De prins geeft de boer wat paddenstoelen.

Daarna neemt de prins afscheid van de boer.

Hij gaat dan lekker in de zon liggen.

3.

Een skiester geeft voer aan haar kippen.

Zij doet het twee keer per week.

Zij wil haar kippen aan een politievrouw laten zien.

De politievrouw vindt de kippen te dik.

Hiermee heeft de politievrouw de skiester beledigd.

Zij gaat liever naar haar huis.

4.

Een zwemmer eet een lekker taartje.

Hij zit al helemaal vol.

Hij belt een kok op.

De kok komt langs.

De kok eet de restjes van de appletaart.

Hij gaat daarna TV kijken.

Verhalen zonder topic shift 
5.

Een boswachter vaart over de zee.

Hij vindt varen heel rustgevend.

Hij vaart samen met een goochelaar.

De boswachter vraagt de goochelaar om een sigaretje.

Toevallig vindt de boswachter nog een sigaretje in zijn tas.

Hij gaat daarna een biertje drinken.

6.

Een non gaat naar de stad.

Zij heeft heel veel geld.

Zij wil heel veel kleiding voor een verpleegster kopen.

Daarna ziet de non een leuk winkeltje.

De kon koop echt heel veel kleiding.

Zij houdt echt veel van kleiding.

7.

Een koningin gaat naar een speeltuin.

Zij wil samen met iemand schommelen.

Zij ontmoet daar een juffrouw.

De koningin vraagt haar om mee te spelen.

Daarna gaat de koningin weer terug naar huis.

Zij gaat nu aardappelen eten.

8.

Een dief zingt een mooi liedje.

Hij heeft op de basisschool leren zingen.

Hij zingt het liedje voor een rechter.

De dief zit bij de rechter te slijmen.

Daarna houdt de dief op met zingen.

Hij gaat liever krant lezen.

Michal Kořenár

University of Reading \& Univerzita Karlova

E-mail:m.korenar@reading.ac.uk 